\title{
Utvis forsiktighet - floskel eller nyttig opplysning?
}

\author{
I preparatomtaler godkjent av Legemiddelverket bes leger til stadighet om «å utvise forsiktighet». \\ Hvordan skal vi forholde oss til dette uttrykket?
}

En erfaren allmennlege ønsket å vurdere oppstart med et av de nye orale antikoagulasjonsmidlene hos en pasient, men leste i preparatomtalen at han måtte «utvise forsiktighet». Han funderte på hva dette kunne bety. Litt humoristisk formulert: Skulle han be pasienten om å være forsiktig med tablettene - se, men ikke røre eller smake, men ikke svelge? Selvsagt er det ikke slik - realiteten er at allmennlegen må ta en konkret beslutning om å forskrive medikamentet eller ikke. Da må konkrete råd være lett tilgjengelige.

Ved søk på ordet *forsiktig* i 20 tilfeldig utvalgte preparatomtaler i Felleskatalogens nettversjon (1) fant vi følgende variasjoner av forsiktighetsbegrepet i 19: «utvis forsiktighet», «forsiktighet bør utvises», «forsiktighet må utvises», «brukes med forsiktighet», «gis med forsiktighet», «behandles med forsiktighet», «titreres med forsiktighet». En nærmere konkretisering av hva som lå i begrepet ble kun gitt $\mathrm{i}$ tre av de 19 preparatomtalene. Følgende sitat fra en av de øvrige viser hvor meningsløs teksten kan være: «Eldre: Ingen dosejustering er påkrevd. Det foreligger begrensede sikkerhetsdata hos pasienter $\geq 75$ år, og forsiktighet må utvises.»)

Vi tar til orde for en oppstramming av forsiktighetsbegrepet i preparatomtaler. Vår oppfatning er at uttrykket $i$ all hovedsak er en innholdsløs floskel som trolig kun tilfredsstiller juristen og sjelden gir meningsfull informasjon eller eksplisitte råd om hvilke spesielle hensyn lege og pasient bør ta.

Det må stilles krav til en presisering av hvilke konkrete tiltak legen bør iverksette når «forsiktighet» er aktuelt, for eksempel unngå bruk av legemidlet, justere dosen, monitorere nyrefunksjonen eller være spesielt årvåken når det gjelder bivirkninger.

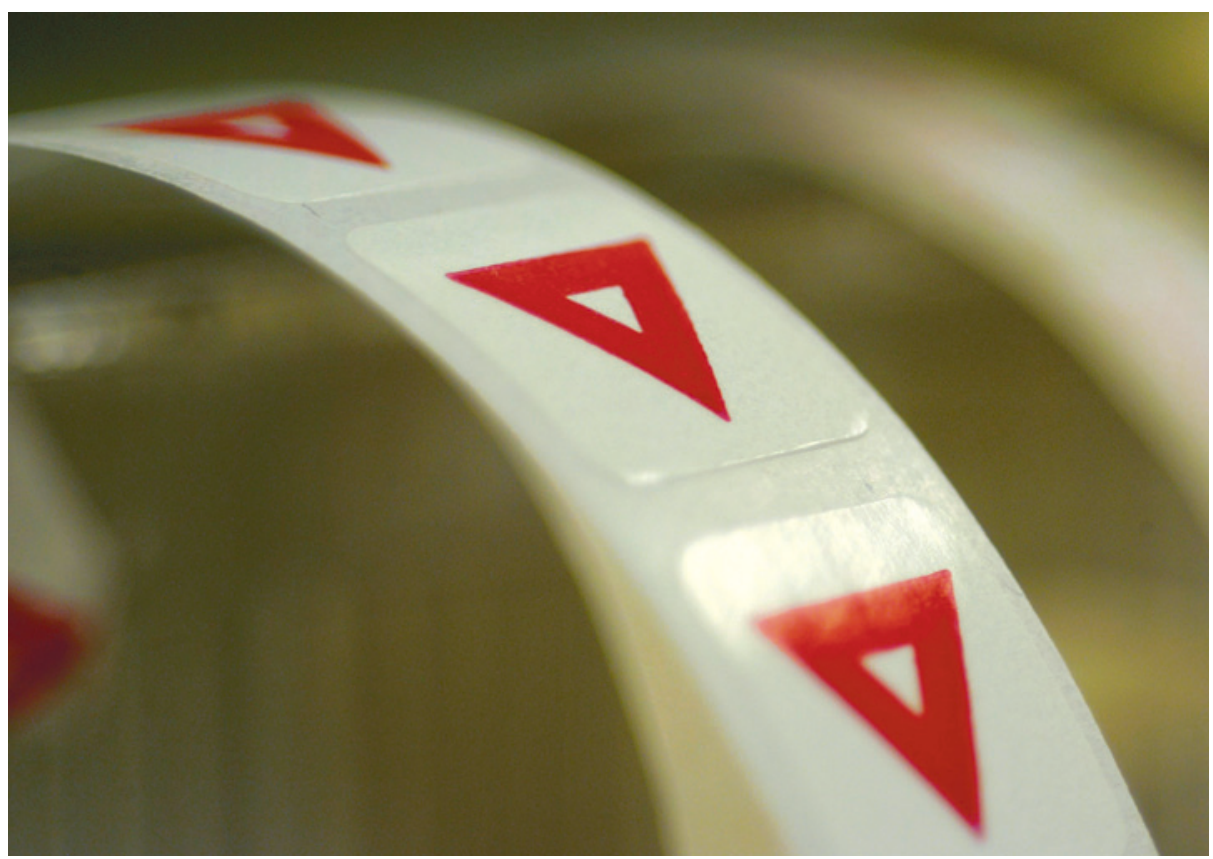

Illustrasjonsfoto NTB scanpix

Vårt råd til Legemiddelverket er derfor: La «forsiktighet» vike for «grundighet»! Der det finnes konkrete råd, bør disse formuleres eksplisitt i teksten. Forsiktighet alene skaper usikkerhet!

\section{Tormod Karlsen Bjånes}

tormod.karlsen.bjaanes@helse-bergen.no Geir Thue

Tormod Karlsen Bjånes (f. 1978) er konstituert overlege ved Laboratorium for klinisk biokjemi, Seksjon for klinisk farmakologi, Haukeland universitetssykehus.
Geir Thue (f. 1953) er spesialist i allmennmedisin og fastlege ved Oasen Legesenter, Fyllingsdalen, Bergen.

Litteratur

1. Felleskatalogen. Preparater A-Z

www.felleskatalogen.no/medisin (20.8.2013).

Mottatt 9.8. 2013 og godkjent 20.8. 2013. Redaktør Marit Fjellhaug Nylund. 